\title{
Highly polymorphic DNA markers in an Africanized honey bee population in Costa Rica
}

\author{
Jorge Arturo Lobo Segura
}

\begin{abstract}
Two genetic markers (the mtDNA COI-COII intergenic region and the microsatellite A7) with high levels of variability in South African and European honey bees were analyzed in wild swarms of Africanized honey bees (Apis mellifera) from Costa Rica. Allelic or haplotypic frequencies revealed high levels of genetic variability at these loci in this population. Most of the alleles were African alleles, although some European-derived alleles were also present. Differences in the frequencies of African alleles between African and Africanized samples were minor, which could be explained by founder effects occurring during the introduction of African honey bee populations into South America.

\section{INTRODUCTION}

Assessment of the genetic diversity in populations of Africanized honey bees has been conducted with genetic markers and multivariate morphometry (Daly and Balling, 1978; Hall and Muraldiharan, 1989; Lobo et al., 1989; Smith et al., 1989; Hall and Smith, 1991; Moritz and Meusel, 1992; Sheppard et al., 1991; Rinderer et al., 1991; McMichael and Hall, 1996). These studies have focused on the identification of Africanized honey bees during their migration into new regions. Genetic and morphometric approaches have also made it possible to study the dynamics of gene flow from these migrant populations to existing populations of other honey bee races in South, Central and North America (Del Lama et al., 1990; Sheppard et al., 1991; Rinderer et al., 1991; Lobo, 1995; Quezada-Euan and Hinsull, 1995; McMichael and Hall, 1996). Although conflicting conclusions have been reported for the degree of admixture between African and European genes in Africanized honey bees, the general pattern of the genetic data demonstrates that Africanized bees are essentially an African-derived population (from the South African subspecies Apis mellifera scutellata). There is, however, an increasing degree of admixture of European races in regions where climatic regimes or past intense beekeeping have allowed greater gene introgression from European honey bee races (Apis mellifera mellifera or Apis mellifera ligustica) (Lobo et al., 1989; Quezada-Euan and Hinsull, 1995). Some relevant aspects of the behavior of Africanized bees, such as the more frequent swarming and absconding, further support the genetic data. A recent multivariate morphometric analysis of Brazilian honey bees showed that morphometric clines correlated well with allele frequency clines at the MDH loci (Diniz-Filho and Malaspina, 1995). These data

suggest that levels of gene flow vary among Africanized honey bee populations.

How much of the genetic variability of ancestral African bees is present in Africanized honey bees is an important question. The existence of founder effects in Africanized bees may have reduced the actual levels of genetic variability in these populations. The initial introduction of the African stock to Brazil consisted of 26 inseminated queens from African stocks selected from Transvaal (South Africa) and Tanganica (Kerr, 1967). The number of queens that effectively contributed genetically to the initial founding of the Africanized populations is unknown. Genetic markers with high variability in South African populations are needed to evaluate the loss of genetic variability in Africanized honey bees compared to the ancestral African genes. Moreover, if the allelic frequencies of these loci are known with sufficient accuracy in different honey bee races, the incorporation of new alleles at the same loci by hybridization can be evaluated. Morphometric differences between South African and Africanized honey bees (Buco et al., 1987), along with differences in behavioral traits, may be partially explained by genetic drift or hybridization with other honey bee races. McMichael and Hall (1996) evaluated the diversity at the $\mathrm{pB} 178$ locus in two Africanized honey bee populations and some Old World honey bee populations. This locus, which has the desired allelic diversity mentioned above, revealed that both genetic admixture (between African and West European honey bee races) and genetic drift may be involved in determining the allelic diversity in Africanized honey bees.

Other genetic markers that possess the desired properties for the study of genetic drift in Africanized honey bees have been discovered. One of these is the COI-COII intergenic region of mitochondrial DNA. Cornuet et al.
\end{abstract}


(1991) showed that this genic spacer has properties homologous to the mtDNA control region in Drosophila. Garnery et al. (1993) studied the extensive polymorphism of this genic region, caused mainly by tandem duplications of a 54-pb sequence, in different honey bee races. Moritz et al. (1994) documented the frequencies of different haplotypes of the COI-COII region in colonies of Apis mellifera scutellata from various localities in South Africa. Hall and Smith (1991) analyzed the variation in the size of this region among different populations of honey bees, including an extensive sample of Africanized honey bees, and found a significant change in the haplotype frequencies of this region when Africanized (Mexico, Central America and Venezuela) and South African populations were compared.

At the level of genomic DNA, some of the microsatellites discovered by Estoup et al. (1993) could also be used with the same objectives. As with microsatellites in natural populations of other organisms, these loci have high intra- and interpopulational variability. Some of the microsatellites, such as A7 and A43, show high heterozygosity in South African populations and most of the alleles are different from those found in other honey bee populations (Estoup et al., 1995).

The objective of this study was to compare the haplotype or allelic diversity in the mtDNA COI-COII intergenic region and the microsatellite A7 between South African and Central American Africanized honey bees. Such a comparison should allow inferences to be made about the influence of genetic drift and racial admixture on the allelic frequencies of these genes.

\section{MATERIAL AND METHODS}

\section{Sampling of swarms}

The sampling of bees was done at Palo Verde National Park, Guanacaste Province, northwestern Costa Rica $\left(10^{\circ} 30^{\prime} \mathrm{N}\right.$ and $\left.85^{\circ} 30^{\prime} \mathrm{W}\right)$. This area is described as tropical dry forest, with an average annual rainfall of $1.6 \mathrm{~m}$ and a well-defined dry season from December to May (Maldonado et al., 1995). The landscape consists of a mixture of mature forest with extensive areas of secondary growth, lagoons and cattle pastures. The vegetation consists predominantly of deciduous trees and shrubs, many of which flower during the dry season. The main swarming season of Africanized honey bees occurs in the last half of this period. The favorable climatic conditions at Palo Verde led to beekeeping with European honey bees prior to the onset of Africanization, which in Costa Rica occurred approximately from 1982 to 1986 (Spivak, 1991).

Samples of wild swarms were obtained using Langstroth hive traps, partially filled with old honey bee combs and placed in trees. The traps were checked weekly for new swarms. Fifty hives were placed at four different sites located $1 \mathrm{~km}$ apart. During each inspection, the entire swarm was collected, and the hive left in place for further collections. Sixty wild swarms were collected during the dry season between December 1995 and April 1996. Most of the swarms were collected at the end of the dry season, which corresponds to the hottest and driest weeks of the year, and were classified as reproductive swarms, based on the large number of drones present.

\section{Molecular analysis}

Total DNA was prepared from the thorax of workers and queens as described by Moritz et al. (1994). One worker from each swarm was used to determine the mtDNA frequencies. Twenty-five queens from different swarms were used to determine the allelic frequencies of the microsatellite locus.

The PCR conditions and primers for the analysis of the intervening COI-COII mitochondrial region were as described by Hall and Smith (1991). The primers ( 5' TCTATACCACGACGTTATTC 3' and 5' GATCAATATC ATTGATGACC 3') bound to nucleotide positions 3090 and 3940, based on the honey bee mitochondrial map of Crozier and Crozier (1993), and allowed the amplification of part of the COI gene, tRNA leu, the intervening region ( $\mathrm{P}$ and $\mathrm{Q}$ repeats) and part of the COII gene. The size of the amplified region varied depending on the particular haplotype of each individual. Five microliters of the PCR products was electrophoresed in $1 \%$ agarose gels to determine the size (in base pairs, bp) of the fragment. Aliquots $(10 \mu \mathrm{l})$ of the amplified DNA were digested with restriction enzymes HinfI and DraI to determine the restriction sites in the intergenic region and the size of the $P$ sequence within the fragment (Garnery et al., 1993). DNA restriction fragments were separated in 3\% Metaphor agarose gels and stained with ethidium bromide, or in 5\% denaturing polyacrylamide sequencing gels and silver stained, using the Promega silver sequence staining kit.

Microsatellite variation was studied at microsatellite A7 (core sequence $(\mathrm{CT})_{3}(\mathrm{~T})_{7} \mathrm{CCTTCG}(\mathrm{CT})_{24}$ ) (Estoup et al., 1995). The PCR conditions were as described elsewhere (Estoup et al., 1995), with the exception that the assay was non-radioactive and was done in a final volume of $30 \mu \mathrm{l}$. Aliquots $(7 \mu \mathrm{l})$ of amplified DNA were mixed with $5 \mu \mathrm{l}$ of formamide solution and $3 \mu \mathrm{l}$ of the mixture, then heated for $5 \mathrm{~min}$ at $85^{\circ} \mathrm{C}$ prior to electrophoresis in $6 \%$ denaturing polyacrylamide sequencing gels. The gels were silver staining with a commercial silver staining kit (Promega). The size of the different alleles was determined using the products of the sequence reaction of the plasmid pGEM -3zf(-) (Promega Catalog No. P 2261) as molecular size markers.

Determination of the exact size of the alleles at microsatellite $\mathrm{A} 7$ proved to be difficult with the above methods, because the core sequence of the A7 locus includes repeats of two and one nucleotides. Thus, even when using a sequence reaction as a control, a given band often 
showed two sizes which differed by two nucleotides. To solve this problem, a score of $1 / 2$ was assigned to each of the two possible sizes for each band. The populational frequencies were calculated using a sum of the scores for all the allele sizes observed. This method provided an approximation of the real frequency distribution, and was sufficiently informative for estimating the genetic similarity with other honey bee races, due to the difference in the mean allele size between African and European races (Estoup et al., 1995).

\section{RESULTS}

Analysis of the COI-COII region in the Africanized colonies from Palo Verde showed that most of the samples possessed some of the haplotypes defined by Estoup et al. (1995). Digestion of the amplified DNA with DraI and HinfI followed by agarose and denaturing acrylamide electrophoresis showed that the size of the amplified DNA varied according to the number of repetitions (13 ) of the Q fragment (192-196 bp), as well as the presence or absence of a P (54 bp) or Po $(67 \mathrm{pb})$ fragment (Cornuet et al., 1991; Garnery et al., 1993) (Figure 2). The total size of the amplified DNA was similar to that described by Hall and Smith (1991). Comparison of some of the haplotypes reported in the latter study with those observed here was not possible because these authors did not use DraI digestions.

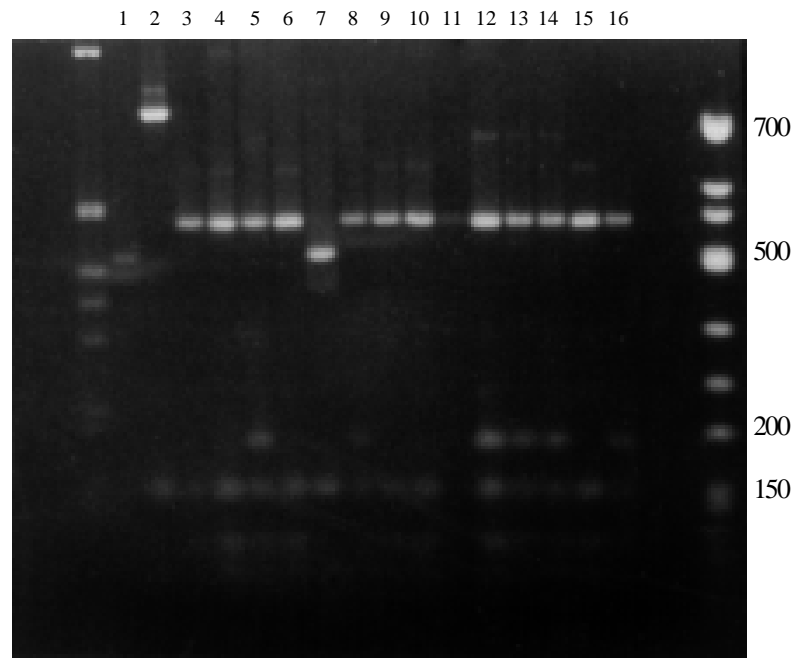

Figure 1 - Agarose gel electrophoresis of $\mathrm{DraI}$ digests of the COI-COII region amplified in workers from different colonies of the Palo Verde Africanized population. Size standards in the outer lanes are 1-kb genetic marker from Life Technologies (left) and $\phi X 174$ digested with HinfI (right). Lanes 1 and 7 show Q haplotype (East European) in wild Africanized swarms. Lanes 3, 4, 6, 9, 10,11 and 15 show the digestion profile of the PoQ haplotype (African), and lanes 5, 8, 12,13, 14 and 16 are the PoQQ haplotype (African), characterized by the presence of an extra band in the 200bp region. Lane 2 is a PQQ sample, with a large fragment resulting from a segment without DraI sites, as revealed by Hinf I digestion.
Determination of the DraI restriction pattern for all of the samples was difficult because some of the digestion patterns may have resulted from different haplotypes. However, most of the samples clearly belonged to the $\mathrm{A} 1(\mathrm{PoQ})$ and A4(PoQQ) haplotypes, both of them with one DraI restriction site per Q sequence (Garnery et al., 1993) (Figure 1). The haplotype frequencies are very similar to those of the Transvaal population, but were not similar to the whole sample from South Africa (Table I). In South Africa about $70 \%$ of the colonies have the PoQQ haplotype. In the Costa Rican Africanized population, the frequency of this haplotype was around 33\%. Europeanderived haplotypes were also found at low frequencies in the Africanized population.

Twenty-five queens were genotyped for the locus A7. The distribution of allele frequencies among Palo Verde populations was compared with selected populations from other continents (Figure 3). Johannesburg (A. m. scutellata), Forli (A. m. ligustica) and Avignon (A. m. mellifera) frequencies were selected from the data of Estoup et al. (1995) because these samples are representative of the races introduced into the Neotropics. The Palo Verde allele frequencies were more similiar to those of the sample from Johannesburg (Figure 3). However, comparison of the location of the distribution revealed some differences compared to the Johannesburg population. In the Africanized populations, the alleles were most frequently $105-108 \mathrm{bp}$ in size, although some were 116-122 pb. This contrasts with 100-103 bp for most alleles in the African population, and the absence of alleles greater than $114 \mathrm{bp}$ in the African population. Alleles of greater size are characteristic of European honey bee races, particularly of the Mediterranean races (Estoup et al., 1995). Unbiased estimates of gene diversity (Nei, 1987) were higher in the Africanized population (0.937) than the respective estimates for the Johannesburg (0.898), Forli (0.810) and Avignon (0.377) populations. No statistically significant differences were found in the shape of the allelic frequency distributions between the Palo Verde and Johannesburg populations (Kolmogoronov-Smirnov test, $\mathrm{D}=0.27, \mathrm{P}>0.05)$. However, these statistics must be interpreted with caution because of the allelic counting method used in the Palo Verde population.

\section{DISCUSSION}

Neither the intergenic COI-COII mitochondrial region nor the A7 microsatellite locus showed comparatively lower levels of variation in this Africanized population. Haplotypic or allelic diversity was higher in the Palo Verde population compared to other honey bee races, possibly because of the admixture of a primarily African gene pool with European-derived genes. In our sample, six of 59 wild swarms showed a European mitochondrial haplotype. These swarms were collected from a dry forest, far from any apiary practicing beekeeping with European queens. Mor- 
Table I - mtDNA haplotype frequencies in the COI-COII region at different localities in Central America, Africa and Europe.

\begin{tabular}{|lccccccccc|}
\hline Haplotypes & PoQ & PoQQ & PoQQ & PQ & PQQ & PQQQ & Q & Others & No. colonies \\
\hline $\begin{array}{l}\text { Locality } \\
\text { Costa Rica } \\
\text { (Palo Verde) }\end{array}$ & 0.559 & 0.339 & - & - & 0.051 & 0.017 & 0.034 & - & 59 \\
$\begin{array}{l}\text { South Africa } \\
\text { (Transvaal) }\end{array}$ & 0.430 & 0.470 & 0.087 & - & - & - & - & - & 23 \\
$\begin{array}{l}\text { South Africa } \\
\text { (miscellaneous) }\end{array}$ & 0.200 & 0.760 & 0.002 & - & - & - & - & 0.020 & 100 \\
$\begin{array}{l}\text { France } \\
\text { (Avignon) }\end{array}$ & - & - & - & 0.069 & 0.860 & 0.069 & - & - & 29 \\
$\begin{array}{l}\text { Italy } \\
\text { (miscellaneous) }\end{array}$ & - & - & - & - & - & - & 1.000 & - & 12 \\
$\begin{array}{l}\text { Spain } \\
\text { (South) }\end{array}$ & 0.063 & 0.718 & 0.063 & 0.031 & 0.125 & - & - & - & 32 \\
$\begin{array}{l}\text { Spain } \\
\text { (Northeast) }\end{array}$ & - & - & - & - & 0.920 & 0.080 & - & - & 25 \\
\hline
\end{tabular}

1- This study; 2- Moritz et al. (1994); 3- Garnery et al. (1993).

$\begin{array}{cccccccccc}0 & 100 & 200 & 300 & 400 & 500 & 600 & 700 & 800 & 900 \mathrm{bp} \\ & 1 & 1 & 1 & 1 & 1 & 1 & 1 & 1 & \end{array}$

\section{PoQ haplotype}

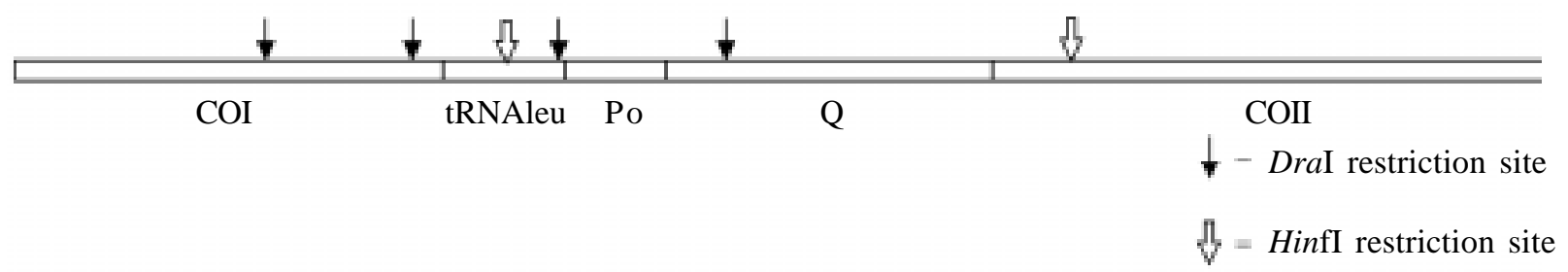

Figure 2 - Schematic representation of the most common mtDNA haplotype (PoQ) in the Africanized honey bee population of Palo Verde. This haplotype corresponds to an African mtDNA lineage.

phometric analysis of a sample of workers from 10 colonies from the same locality (Lobo, 1995) showed that the honey bees clearly had the Africanized morphometric pattern. These results are similar to those of Lobo (1995), Moritz and Meusel (1992) and Quezada-Euan and Hinsull (1995), who found low but appreciable frequencies of European DNA mitotypes in morphometrically Africanized populations. However, other studies, such as those of Smith et al. (1989), Hall and Muraldiharan (1989) and Sheppard et al. (1991), did not detect European mitochondrial DNA in samples of Africanized honey bees. If the frequency of European mitochondrial DNA were low in most of the Africanized populations, the contradictory results above could easily be explained by geographic variation, temporal changes in frequencies, sampling methods or the amount of racial differentiation in the mitochondrial DNA region chosen as a molecular marker.
As regards the status of the South African genetic polymorphisms in the Africanized population, it is notable that most of this variation has been found during migration of these bees through South America. If one compares the Africanized sample with the data of Garnery et al. (1993) and Moritz et al. (1994) from the Pretoria region, the changes in gene frequencies have been minimal, except for the absence of the mitochondrial haplotype PoQQQ (frequency of 0.087 in Transvaal) and the apparent absence of a peak of frequencies in the A 7 locus in the 100 -bp region. In the latter case, more extensive sampling in both regions is necessary to confirm this difference.

When the Africanized COI-COII haplotype frequencies are compared to the data for all of South Africa (Moritz et al., 1994), a shift in frequencies is noted since PoQQ is the most frequent haplotype in South Africa. This observation may be extended to a comparison of other 


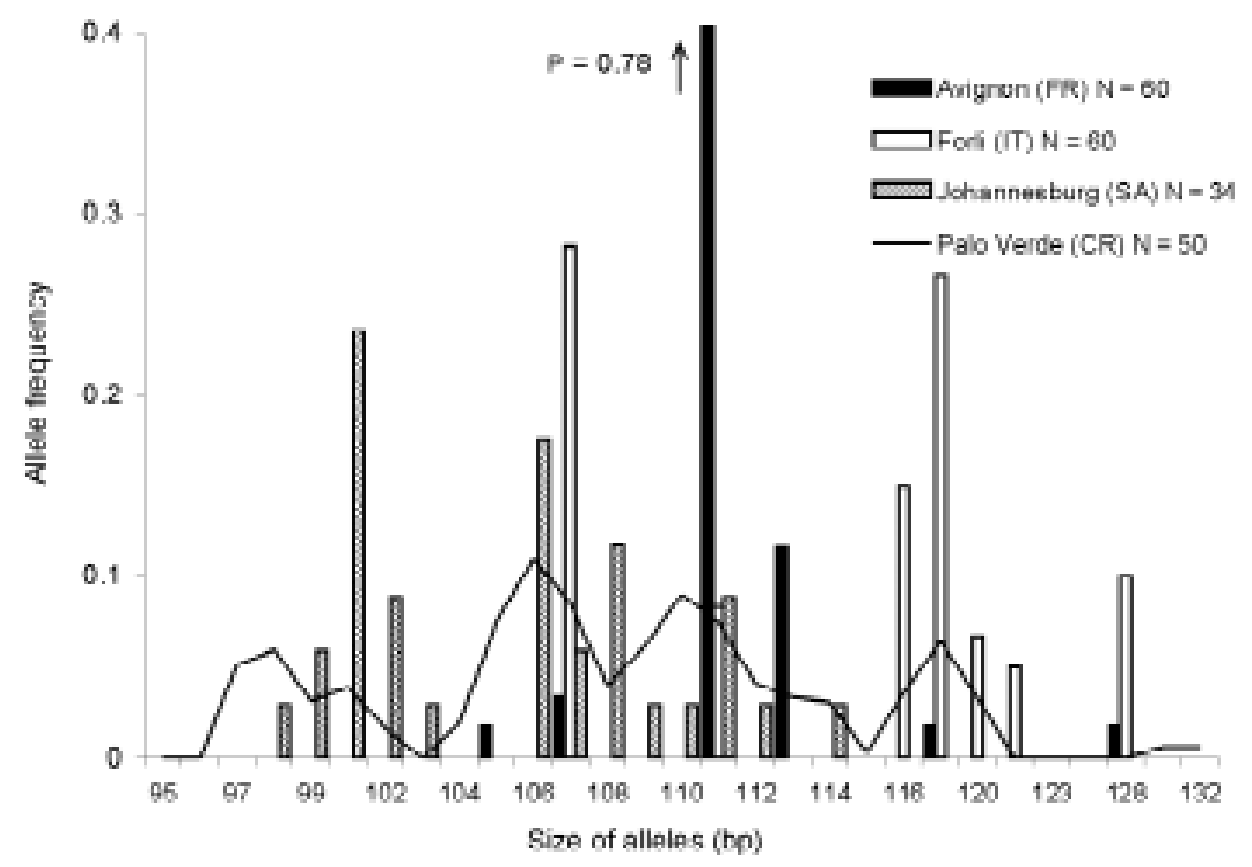

Figure 3 - Gene frequency distribution for Africanized, African and European honey bee populations at locus A7. The data are from Estoup et al. (1995), except for the Palo Verde populations (this study). $\mathrm{N}$ is the number of alleles sampled in each population. The symbol $\mathrm{P}=0.78 \uparrow$ means an allele frequency of 0.78 for the 111 -bp allele in the Avignon population.

Africanized populations with that of African bees in South Africa. A shift in mtDNA frequencies was also noted by Hall and Smith (1991) when they compared the frequencies of different "insert sizes" between South African and Africanized samples from Venezuela, Costa Rica and Honduras (36 Africanized colonies). This shift was interpreted as reflecting genetic drift. Moritz et al. (1994) showed that the frequency of the PoQ haplotype increased progressively from $0 \%$ to $50 \%$ along a south-north transect in South Africa. Thus, the differences between South African and Africanized samples could be partly a result of the selection of an ancestral sample of queens from the Transvaal region, which would not be representative of the diversity of gene frequencies from all of South Africa.

The mtDNA haplotype frequencies of the Palo Verde populations in Costa Rica did not differ much from those of Africanized populations from other Latin American countries (Hall and Smith, 1991). This fact, combined with the similarity in the gene frequencies at the A7 locus between the Johannesburg and Palo Verde populations, shows that dramatic reductions in the effective population size during the initial settling and posterior migration of Africanized populations were very unlikely, and that most of the founder queens survived and swarmed successfully, given that the founder population consisted of the 26 escaped queens from Rio Claro, São Paulo State, in 1956 (Kerr, 1967). A high level of relatedness between the initial colonies can also be rejected since a founder population consisting of sister or mother-daughter queens could not produce the observed mtDNA variability. The high allelic diversity at the A7 locus may be explained by the representative sampling of nuclear genes when mated queens were the founder stock of new honey bee populations. Multiple mating during the nuptial flight of honey bee queens assures that each mated queen carries a sample of 12-18 unrelated drones in her spermathecae (Lobo and Kerr, 1993).

McMichael and Hall (1996) found that Africanized (Mexico and Honduras) and African (Transvaal) populations did not share most of the RFLP alleles revealed by two restriction enzymes at a highly polymorphic locus detected with a genomic probe (probe pb178). However, African and Africanized alleles were highly related, and many African alleles clustered with Africanized alleles in dendrograms. These two facts can be interpreted as the expected loss of low frequency alleles during the introduction of Africanized bees, but also shows that Africanized alleles at this locus did not originate from a few African ancestors. Again, for both the A7 and the pb178 loci, more samples of Africanized and African colonies are necessary to provide a better picture of the effects of genetic drift and hybridization in Africanized bees.

The above considerations indicate that Africanized honey bee populations are very representative of the genetic variation of African bees from the Transvaal region of South Africa. The loss of some rare alleles during the initial introduction has been balanced by the introgression of European alleles through posterior hybridization. As a 
result, the introduction of new genetic material from South Africa or from other continents with the aim to improve the genetic diversity for breeding programs (Fletcher, 1991 ) is not supported by the present data. Instead, breeding programs using selected queens from feral and managed Africanized populations would be a useful strategy for producing improved commercial lineages of Africanized bees.

\section{ACKNOWLEDGMENTS}

The author thanks M. Quesada, K. Stoner, E. Fuchs, J.L. Weng and $\mathrm{G}$. Jones for providing invaluable assistance in the field. This work was supported by the International Foundation for Science (grant B/1975-2) and by the Vicerrectoría de Investigación de la Universidad de Costa Rica (grant 111-96-270).

\section{RESUMO}

Dois marcadores genéticos (a região intergénica mitocondrial COI-COII e o microsatélite A7), com altos níveis de variabilidade em populações de abelhas melíferas da África do Sul e Europa, foram analisados em uma amostra de enxames naturais da Costa Rica. As frequiências alélicas e haplotípicas na amostra africanizada mostraram altos níveis de diversidade nestes loci. A maioria dos alelos são de origem africana, embora alguns alelos de origem européia foram observados. As mudanças nas frequiências dos alelos de origem africana entre as abelhas da África do Sul e as abelhas da população africanizada são de baixa magnitude e podem ter sido causadas pelo efeito fundador que ocorreu na introdução da abelha africana na América do Sul.

\section{REFERENCES}

Buco, M.S., Rinderer, T.E., Sylvester, H.A., Collins, A.M., Lancaster, V.A. and Crewe, R.M. (1987). Morphometric differences between South American Africanized and South African (Apis mellifera scutellata) honey bees. Apidologie 18: 217-222.

Cornuet, J.M., Garnery, L. and Solignac, M. (1991). Putative origin and function of the intergenic region between COI and COII of Apis mellifera L. mitochondrial DNA. Genetics 128: 393-403.

Crozier, R.H. and Crozier, Y.C. (1993). The mitochondrial genome of the honey bee Apis mellifera: complete sequence and genome organization. Genetics 133: 97-117.

Daly, H.V. and Balling, S.S. (1978). Identification of Africanized honey bees in the Western Hemisphere by discriminant analysis. J. Kans. Entomol. Soc. 51: 857-869.

Del Lama, M.A., Lobo, J.A., Soares, A.E.E. and Del Lama, S.N. (1990). Genetic differentiation estimated by isozymic analysis of Africanized honey bee populations from Brazil and from Central America. Apidologie 21: 271-280.

Diniz-Filho, J.A.F. and Malaspina, O. (1995). Evolution and population structure of Africanized honey bees in Brazil: evidence from spatial analysis of morphometric data. Evolution 49: 1172-1179.

Estoup, A., Garnery, L., Solignac, M. and Cornuet, J.M. (1995). Microsatellite variation in honey bee (Apis mellifera L.) populations: hierarchical genetic structure and test of the infinite allele and stepwise mutation models. Genetics 140: 679-695.

Fletcher, J.C. (1991). Interdependence of genetics and ecology in a solution to the African bee problem. In: The "African" Honey Bee (Spivak, M., Fletcher, D.J. and Breed, M.D., eds.). Westview Press, Boulder, CO, pp. 77-94.

Garnery, L., Solignac, M., Celebrano, G. and Cornuet, J.M. (1993). A simple test using restricted PCR-amplified mitochondrial DNA to study the genetic structure of Apis mellifera L. Experientia 49: 1016-1021.

Hall, H.G. and Muraldiharan, K. (1989). Evidence from mitochondrial DNA that African honey bees spread as continuous maternal lineages. $\mathrm{Na}$ ture 339: 211-213.

Hall, H.G. and Smith, D.R. (1991). Distinguishing African and European honey bee matrilines using amplified mitochondrial DNA. Proc. Natl. Acad. Sci. 88: 4548-4552.

Kerr, W.E. (1967). The history of the introduction of African bees to Brazil. S. Afr. Bee J. 39: 3-5.

Lobo, J.A. (1995). Morphometric, isozymic and mitochondrial variability of Africanized honey bees in Costa Rica. Heredity 75: 133-141.

Lobo, J.A. and Kerr, W.E. (1993). Estimation of the number of matings in Apis mellifera: extensions of the model and comparison of different estimates. Ethol. Ecol. \& Evol. 5: 337-345.

Lobo, J.A., Del Lama, M.A. and Mestriner, M.A. (1989). Population differentiation and racial admixture in the Africanized honey bee (Apis mellifera L.). Evolution 43: 794-802.

Maldonado, T., Bravo, J., Castro, G., Jiménez, Q., Saborio, O. and Paniagua, L. (1995). Evaluación Ecológica Rápida Región del Tempisque, Guanacaste, Costa Rica. Fundación Neotrópica, San José, Costa Rica.

McMichael, M. and Hall, H.G. (1996). DNA RFLPs at a highly polymorphic locus distinguish European and African subspecies of the honey bees (Apis mellifera L.) and suggest geographical origins of New World honey bees. Mol. Ecol. 5: 403-416.

Moritz, R.F.A. and Meusel, M.S. (1992). Mitochondrial gene frequencies in Africanized honey bees (Apis mellifera L.): Theoretical model and empirical evidence. J. Evol. Biol. 5: 71-81.

Moritz, R.F.A., Cornuet, J.M., Kryger, P., Garnery, L. and Hepburn, H.R. (1994). Mitochondrial DNA variability in South African honey bees (Apis mellifera L.). Apidologie 25: 169-178.

Nei, M. (1987). Molecular Evolutionary Genetics. Columbia University Press, New York.

Quezada-Euan, J.J.G. and Hinsull, S.M. (1995). Evidence of continued European morphometrics and mtDNA in feral colonies of honey bees (Apis mellifera) from Yucatán Peninsula, Mexico. J. Apic. Res. 34: 161-166.

Rinderer, T.E., Stelzer, J.A., Oldroyd, B.P., Buco, S.M. and Rubink, W.L. (1991). Hybridization between European and Africanized honey bees in the Neotropical Yucatán Peninsula. Science 253: 309-311.

Sheppard, W.S., Soares, A.E.E., DeJong, D. and Shimanuki, H. (1991). Hybrid status of honey bee populations near the historic origin of Africanization in Brazil. Apidologie 22: 643-652.

Smith, D.R., Taylor, O. and Brown, W.M. (1989). Neotropical Africanized honey bees have African mitochondrial DNA. Nature 339: 213-215.

Spivak, M. (1991). The Africanization process in Costa Rica. In: The "African" Honey Bee (Spivak, M., Fletcher, D.J. and Breed, M.D., eds.). Westview Press, Boulder, CO, pp. 137-155.

(Received March 30, 1999) 